\title{
Four Near-Isogenic Lines of Cotton with Different Genes for Bacterial Blight Resistance
}

\author{
Margaret Essenberg, Melanie B. Bayles, Roushan A. Samad, Judy A. Hall, \\ L. A. Brinkerhoff, and Laval M. Verhalen
}

First through fourth authors: Department of Biochemistry and Molecular Biology; fifth author: Department of Plant Pathology, L. A. Brinkerhoff is deceased; and sixth author: Department of Plant and Soil Sciences, Oklahoma State University, Stillwater 74078. Accepted for publication 12 July 2002.

\begin{abstract}
Essenberg, M., Bayles, M. B., Samad, R. A., Hall, J. A., Brinkerhoff, L. A., and Verhalen, L. M. 2002. Four near-isogenic lines of cotton with different genes for bacterial blight resistance. Phytopathology 92:13231328

The development and genetic characterization of four near-isogenic lines (NILs) of cotton (Gossypium hirsutum) is described herein. Each line contains a single, but different, gene for resistance to bacterial blight

'Acala 44', followed by single plant-progeny row selection for uniformity. The NILs are homozygous for the $B_{2}, B_{4}, B_{I n}$, or $b_{7}$ genes and are designated as $\mathrm{Ac} B_{2}, \mathrm{Ac} B_{4}, A c B_{I n}$, and $A c b_{7}$, respectively. In the 'Acala 44' background, $B_{2}, B_{4}$, and $B_{I n}$ are partially dominant genes; $b_{7}$ is partially recessive. Relative strengths of resistance conferred by those genes toward race 1 of the pathogen were $B_{4} \sim b_{7}>B_{I n} \sim B_{2} . B_{4}, B_{I n}$, and $b_{7}$ each conferred resistance toward $X$. campestris pv. malvacearum carrying a single avirulence gene, whereas $B_{2}$ was less specific.
\end{abstract} caused by Xanthomonas campestris pv. malvacearum. The lines were derived using at least six backcrosses to the susceptible recurrent parent
Additional keywords: avirulence genes, disease resistance.
Bacterial blight, incited by Xanthomonas campestris pv. malvacearum, is the only major bacterial disease of cotton (Gossypium spp.). In many cotton-growing regions of the world, it reduces lint yield (4) and fiber quality (18). Even though sanitation, quarantine, and various seed treatments have been successfully used as cultural controls, resistant cultivars are generally considered the most effective and dependable method for controlling the disease (3). At least 16 major genes have been identified that confer complete or partial resistance to one or more races of the pathogen (6). Those genes were derived from a number of sources and genetic backgrounds (5). Knight $(14,15)$ transferred $B_{2}$ and $B_{4}$ plus seven other blight-resistance genes into Sudan Sakel (Gossypium barbadense) strains to assess their value for breeding purposes. In the $1950 \mathrm{~s}$, Bird (2) transferred $B_{2}, B_{4}$, and other genes from Knight's Sakel lines into the upland $(G$. hirsutum) cvs. Empire and Deltapine. The $b_{7}$ gene was discovered in 'Stoneville 20' (G. hirsutum) by Green and Brinkerhoff (11). The $B_{\text {In }}$ gene was found in a $G$. hirsutum cultivar of unknown origin near Indiahoma, $\mathrm{OK}$, by Green and Brinkerhoff (11). In 1968, Hunter et al. (13) reported they had derived seven permanent and one temporary G. hirsutum differential host lines that could distinguish among 15 races of $X$. campestris pv. malvacearum. Those lines were selected because they provided reasonably consistent pathogen race differentiation at a number of locations and not because of any genetic relatedness to each other.

A set of near-isogenic lines (NILs) with single, but different, genes for bacterial blight resistance would be useful for studying the physiological and biochemical mechanisms of resistance. To make such studies possible, Hunter and Brinkerhoff (12) began to transfer genes for resistance from several Gossypium spp. into $G$.

Corresponding author: M. Essenberg; E-mail address: margess@biochem.okstate.edu

Publication no. P-2002-1026-01R

(c) 2002 The American Phytopathological Society hirsutum 'Acala 44', a highly susceptible genotype with no known genes for bacterial blight resistance. The crosses were initiated in the greenhouse in the winter of 1959 to 1960, and the first backcrosses to 'Acala 44' were made in the field in 1960 (12). Subsequently, Brinkerhoff made at least three additional backcrosses to 'Acala 44' using one source of resistance to develop the Ac $b_{7}$ line. The other lines described herein were backcrossed one to three times apiece.

In 1991, De Feyter and Gabriel (8) reported the cloning and identification of six avirulence (avr) genes from $X$. campestris pv. malvacearum. Each of these, when introduced into a widely virulent strain of the same organism, conferred avirulence toward one or more of Hunter and Brinkerhoff's (12) resistant Acala lines, most of which had only one backcross to the recurrent parent. Later, De Feyter et al. (9) tested interactions between $X$. campestris pv. malvacearum strains carrying individual avr genes and resistant Acala lines which had been backcrossed two to six times, but which had not yet been subjected to genetic analysis. They indicated that some of the resistance genes $\left(B_{4}, b_{6}, b_{7}\right.$, and $B_{I n}$ ) were specific for single $a v r$ genes, i.e., a cotton line carrying one of those genes was resistant to only one of the bacterial strains which carried individual avr genes. Other resistance genes $\left(B_{1}, B_{2}\right.$, and $\left.B_{I n 3}\right)$ appeared to recognize multiple $a v r$ genes. Nevertheless, a detailed restriction fragment length polymorphism (RFLP) genetic map indicated that $B_{2}$ is located in a single region on the Dsubgenome chromosome 20 (20).

This report describes the development and genetic characterization of four NILs of cotton carrying bacterial blight-resistance genes $B_{2}, B_{4}, B_{I n}$, or $b_{7}$. These lines are hereafter designated as $\mathrm{Ac} B_{2}, A c B_{4}, A c B_{I n}$, and $A c b_{7}$, respectively. When inoculated under Oklahoma field conditions, their levels of resistance to an aggressive strain of $X$. campestris pv. malvacearum race 1 , which possesses many avirulence genes, were compared with those of the resistant parent lines. Their interactions with De Feyter and Gabriel's (8) isogenic strains of $X$. campestris pv. malvacearum carrying individual $a v r$ genes were tested under growth chamber containment. 


\section{MATERIALS AND METHODS}

Genetic stocks and breeding procedures. Hunter and Brinkerhoff's (12) backcross program was suspended by Brinkerhoff's retirement in 1979, but was resumed by Essenberg in 1984. At least five additional backcrosses have now been made to 'Acala 44' (with the last two or more made to Acala 44E) for each of the lines described in this report. Acala $44 \mathrm{E}$ is a single plant selection made by Essenberg from Brinkerhoff's original 'Acala 44' parent (5). Selection was based on its general morphology, which was characteristic of 'Acala 44', but with more abundant flowering.

Two cotton nurseries were utilized during the development of these NILs-a summer nursery near Perkins, OK, on a Teller loam soil (a fine-loamy, mixed, active, thermic Udic Argiustoll) and a winter nursery near Tecomán, Mexico, on a La Escondida silty clay loam soil (a fine, smectitic, mixed, isohyperthermic Calcidic Argiustoll). Disease screenings as well as the backcrosses to 'Acala 44' or Acala 44E were made at Perkins. The winter nursery was used to increase seed stocks of parents and to advance $F_{1}$ populations of the backcrosses to the $F_{2}$ by selfpollination. In addition, the crosses to verify the inheritance of the genes in the NILs were made in Mexico.

After each backcross, the $F_{2}$ populations were screened before flowering by spray inoculation (described below) at Perkins, susceptible plants were rogued, and those remaining were used as parents for the next backcross. After each line had received at least six backcrosses to 'Acala 44' or Acala 44E, selected plants were self-pollinated and individually harvested. The following summer, in each line, four to seven progeny rows (which each traced back to a single plant) were planted, spray-inoculated, and screened. One progeny row with uniform resistance was selected to be the final NIL for that gene. Each progeny row had at least 16 uniformly resistant plants and had none with the more susceptible grades of 2.3 or 4.0 (explained below). Crosses were then made to measure the degree of dominance for each gene as well as to test the hypothesis that the resistance was inherited as a single locus.

Disease resistance screening was conducted in the field or in growth chambers, depending upon the nature of the testing being done and the strains being utilized.

Pathogen isolates. Initial screening of the NILs was accomplished with X. campestris pv. malvacearum race 1 isolates from the collection maintained by Brinkerhoff (6). Subsequent work

TABLE 1. Strains of Xanthomonas campestris pv. malvacearum used in this study

\begin{tabular}{|c|c|c|}
\hline Strain & $\begin{array}{l}\text { Relevant genotype or } \\
\text { phenotype }\end{array}$ & Reference \\
\hline Field isolates & Race 1 , widely avirulent & Brinkerhoff (6) \\
\hline 3631 & $\begin{array}{l}\text { Race } 1 \text {, widely avirulent, } \\
\operatorname{Sm}^{\mathrm{R} z}\end{array}$ & Pierce et al. (17) \\
\hline $\mathrm{H}$ & Race 1 , widely avirulent & De Feyter and Gabriel (8) \\
\hline 1003/pUFR042 & $\begin{array}{l}\text { Widely virulent, plasmid } \\
\text { contains no insert }\end{array}$ & De Feyter and Gabriel (8) \\
\hline \multirow[t]{2}{*}{ 1003/pUFR123 } & $\begin{array}{l}\text { Contains pUFR042 } \\
\text { carrying an } 11.6 \mathrm{~kb}\end{array}$ & De Feyter and Gabriel \\
\hline & $\begin{array}{l}\text { EcoR1 fragment } \\
\text { containing } a v r B_{4}\end{array}$ & (unpublished) \\
\hline 1003/pUFR127 & $\begin{array}{l}\text { Contains pUFR042 } \\
\text { carrying } \text { avrb }_{6}\end{array}$ & De Feyter and Gabriel (8) \\
\hline 1003/pUFR163 & $\begin{array}{l}\text { Contains pUFR } 042 \\
\text { carrying } \text { avrb }_{7}\end{array}$ & De Feyter et al. (9) \\
\hline 1003/pUFR156 & $\begin{array}{l}\text { Contains pUFR042 } \\
\text { carrying } a v r B_{I n}\end{array}$ & De Feyter et al. (9) \\
\hline 1003/pUFR142 & $\begin{array}{l}\text { Contains pUFR } 047 \\
\text { carrying } \text { avrB } B_{101}\end{array}$ & De Feyter et al. (9) \\
\hline 1003/pUFR157 & $\begin{array}{l}\text { Contains pUFR } 042 \\
\text { carrying } a v r B_{102}\end{array}$ & De Feyter et al. (9) \\
\hline
\end{tabular}

${ }^{\mathrm{z}}$ Streptomycin resistant. utilized the strains listed in Table 1 . The crosses to determine degree of dominance and inheritance were all screened in the field with strain 3631 (17). The 1003 strains were in a wild-type African strain background with a wider host range than New World strains (8). Therefore, they were used only in biocontainment environments.

All of the strains except Brinkerhoff's race 1 and strain 3631 were provided by D. W. Gabriel. Plasmid pUFR047 was derived from plasmid pUFR042 by replacing the gene for kanamycin resistance with a gene for ampicillin resistance (9), a change that had no detected effect on pathogenicity or host range of X. campestris pv. malvacearum. Although strain 3631 was derived from a field isolate that exhibited race 3 phenotype [virulent in G. hirsutum 1-10B, which possesses the bacterial blight-resistance gene $\left.B_{I n}(6)\right]$ in $1978(10,17)$, in the work described here it exhibited race 1 phenotype [avirulent in all the differential lines carrying resistance genes (6)]. Cultures were maintained frozen at $-70^{\circ} \mathrm{C}$ in $14 \%$ (vol/vol) glycerol in Bacto nutrient broth (Difco Laboratories, Detroit, MI).

Resistance screening in the field. Segregating $\mathrm{F}_{2}$ populations from each of the NILs were planted at Perkins to identify those plants carrying the desired resistance genes. In subsequent years, parental, $\mathrm{F}_{1}, \mathrm{~F}_{2}$, and backcross populations were also included. Progeny rows were spaced $100 \mathrm{~cm}$ apart and were $10.5 \mathrm{~m}$ long. Plants in each row were thinned to approximately $30 \mathrm{~cm}$ prior to inoculation.

Inoculum was prepared by culturing $X$. campestris pv. malvacearum 3631 (race 1) in nutrient broth at $30^{\circ} \mathrm{C}$ with shaking $(\approx 150 \mathrm{rpm})$ to late logarithmically growing phase $\left(\approx 10^{9} \mathrm{CFU} \mathrm{ml}{ }^{-1}\right)$. Cultures were taken to the field, kept out of direct sunlight, and diluted to 1 to $5 \times 10^{6} \mathrm{CFU} \mathrm{ml}^{-1}$ in unchlorinated well water just prior to use. Plants were inoculated at approximately the six to seven true-leaf growth stage by spraying the bacterial suspension onto the abaxial surface of several leaves on each plant. Spraying was done with a single-nozzle, orchard-type spray gun operating at a pressure of approximately 1.0 to $1.4 \times 10^{6} \mathrm{~Pa}$. Up to $50 \%$ of the total leaf area of each plant was infiltrated. Viability and pathogenicity of each tank of inoculum was checked by syringe inoculation into susceptible Acala 44E just before the tank was emptied, followed by examination of those inoculated areas for disease symptoms at 1 to 2 weeks.

Plants were classified for disease reactions beginning approximately 14 days after inoculation. Scores were recorded for each plant based on the scale described by Brinkerhoff et al. (7). The disease grading scale is based on the size and shape of visible lesions: 0 = immune, no visible lesions; 1 = resistant, dry, small, round to angular lesions; and $4=$ susceptible, large $(1$ to $2 \mathrm{~mm})$, water-soaked, angular lesions that turn black on drying plus up to $0.5 \mathrm{~cm}$-long water-soaked vein lesions. Four additional grades were used to describe mesothetic reactions: 0.1 and $0.2=$ predominantly immune with a few pinpoint $(0.1)$ to small, round (0.2) lesions; 1.2 = resistant, predominantly small, angular lesions, but with small, round lesions also present; and 2.3 = intermediate, predominantly small, angular lesions but with large, water-soaked, angular lesions also present. Susceptible and intermediate plants were removed, and only those plants with resistant and immune phenotypes were used for backcrosses.

To facilitate the determination of a mean bacterial blight grade to estimate degree and direction of dominance, a disease index was established for plants graded in the field. That index corrsponded to the field grades (in parentheses) as follows: $0(0.0), 1$ (0.1), 2 (0.2), 3 (1.0), 4 (1.2), 5 (2.3), and 6 (4.0). The presumption of such an index is of equidistance between field grades. It assumes that the genetic distance (or difference) between 0.0 and 0.1 is equivalent to that between 2.3 and 4.0, etc. Other indexes could easily have been derived, but they would have the same shortcoming in that there is not an objective way to choose "the best" one. Segregation data from the field were analyzed using 
chi-square procedures (19). Plants grading 2.3 and 4.0 were classified as "susceptible", while those grading 1.2 or less were classified as "resistant" (7), unless otherwise noted. Mid-parent values and degrees of dominance were calculated, where possible, using standard definitions (1).

Tests of host/race specificity. Cotton plants were grown in a peat/vermiculite mixture (Jiffy Mix Plus, Jiffy Products of America, Batavia, IL) in growth chambers with a 14-h light/10-h dark cycle. Maximum air temperature during the photoperiod was $30^{\circ} \mathrm{C}$; minimum temperature during the dark period was $19^{\circ} \mathrm{C}$. Plants were fertilized weekly with a mineral mixture (Miracle-Gro All Purpose Plant Food, Scotts Miracle-Gro Products, Inc., Port Washington, NY). Each of the NILs was tested for host/race specificity. These tests included 14 to 20 plants of the NIL plus two plants each of Acala 44E and line Im216 (7) to check the susceptible and immune extremes, respectively, of the disease grading scale. Inoculation was done 6 to 15 weeks after planting, using the youngest, fully expanded leaves. Transparent plastic bags were placed over the leaves 1 to $2 \mathrm{~h}$ before inoculation to encourage stomatal opening in response to the increased humidity. Inocula of $X$. campestris pv. malvacearum $\mathrm{H}$ (race 1) and the seven 1003 strains (Table 1) were prepared by diluting late logarithmic phase nutrient broth cultures in sterile, saturated $\mathrm{CaCO}_{3}$ solution to $\approx 5 \times$

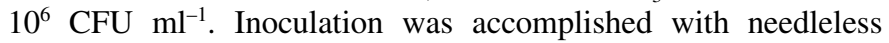
syringes through open stomata on the abaxial leaf surface. A single leaf of each plant was inoculated in four places with each of the strains being tested.
Disease grades of plants in the growth chamber were evaluated every 2 days, beginning 7 days postinoculation. The grades reported here are those recorded on the day for each strain when the highest average grade was attained, usually 11 or 13 days postinoculation. The disease grade scale was based on the sizes of the macroscopically visible water-soaked areas: $0=$ no water-soaking; $1=$ pinpoint-sized dots $; 2=$ small, round speckles $(\approx 0.3 \mathrm{~mm}) ; 3=$ merged angular patches; and $4=$ confluent areas. Intermediate grades between each of the established grades, e.g., 1.3, 2.7, and 3.3, were sometimes recorded.

For each NIL, the growth chamber data consisted of the disease grades attained by each of eight strains of $X$. campestris pv. malvacearum in a set of 14 to 20 plants. The grades attained by any two strains on a given plant were considered paired data. The paired sample $t$ test was used to determine whether responses of the NIL to those two strains differed at the 0.05 probability level.

\section{RESULTS}

The segregation data support the conclusion that the NILs for $B_{2}, B_{4}$, and $B_{I n}$ each possess a single gene for resistance (Table 2). Those genes were dominant to some degree, confirming the original reports describing them $(11,14,16)$. The original model that defined "resistance" as grades 0.0 through 1.2 inclusive and defined "susceptible" as grades 2.3 and 4.0 did not work as well for the NIL containing $b_{7}$. When the susceptible class was expanded to include plants with grades of 1.2, the line was not rejected by

TABLE 2. Bacterial blight reactions of parental, $\mathrm{F}_{1}$, backcross, and $\mathrm{F}_{2}$ populations inoculated in the field with race 1 of Xanthomonas campestris pv. malvacearum

\begin{tabular}{|c|c|c|c|c|c|c|}
\hline \multirow[b]{2}{*}{ Near-isogenic line $\mathrm{u}^{\mathrm{u}}$} & \multirow[b]{2}{*}{ Population } & \multirow[b]{2}{*}{ Hypothesis tested } & \multicolumn{2}{|c|}{ Number of plants } & \multirow[b]{2}{*}{$\chi^{2}$} & \multirow[b]{2}{*}{$P$} \\
\hline & & & $\mathrm{R}^{\mathrm{v}}$ & $\mathrm{S}^{\mathrm{w}}$ & & \\
\hline $\mathrm{AcB} B_{2}{ }^{\mathrm{x}}$ & $\begin{array}{l}\text { Acala } 44 \mathrm{E} \\
\text { AcB } B_{2} \\
\text { Acala } 44 \mathrm{E} \times\left(\text { Acala } 44 \mathrm{E} \times \mathrm{Ac} B_{2}\right) \\
\text { Ac } B_{2} \times\left(\text { Acala } 44 \mathrm{E} \times \mathrm{Ac} B_{2}\right) \\
\left(\text { Acala } 44 \mathrm{E} \times \mathrm{Ac} B_{2}\right) \mathrm{F}_{2}\end{array}$ & $\begin{array}{l}(0: 1) \\
(1: 0) \\
(1: 1) \\
(1: 0) \\
(3: 1)\end{array}$ & $\begin{array}{r}0 \\
30 \\
70 \\
95 \\
231\end{array}$ & $\begin{array}{r}192^{\mathrm{y}} \\
0 \\
55 \\
0 \\
67\end{array}$ & $\begin{array}{l}1.57 \\
0.88\end{array}$ & $\begin{array}{l}0.20-0.30 \\
0.30-0.50\end{array}$ \\
\hline $\mathrm{Ac} B_{4}$ & $\begin{array}{l}\text { Acala } 44 \mathrm{E} \\
\text { AcB } B_{4} \\
\left(\text { Acala } 44 \mathrm{E} \times \mathrm{Ac} B_{4}\right) \mathrm{F}_{1} \\
\text { Acala } 44 \mathrm{E} \times\left(\mathrm{Acala} 44 \mathrm{E} \times \mathrm{Ac} B_{4}\right) \\
\text { Ac } B_{4} \times\left(\mathrm{Acala} 44 \mathrm{E} \times \mathrm{Ac} B_{4}\right) \\
\left(\text { Acala } 44 \mathrm{E} \times \mathrm{Ac} B_{4}\right) \mathrm{F}_{2}\end{array}$ & $\begin{array}{l}(0: 1) \\
(1: 0) \\
(1: 0) \\
(1: 1) \\
(1: 0) \\
(3: 1)\end{array}$ & $\begin{array}{r}0 \\
31 \\
14 \\
12 \\
31 \\
188\end{array}$ & $\begin{array}{r}192^{\mathrm{y}} \\
0 \\
0 \\
14 \\
0 \\
59\end{array}$ & $\begin{array}{l}0.04 \\
0.11\end{array}$ & $\begin{array}{l}0.70-0.90 \\
0.70-0.90\end{array}$ \\
\hline $\mathrm{Ac} B_{I n}$ & $\begin{array}{l}\text { Acala } 44 \mathrm{E} \\
\text { Ac } B_{I n} \\
\left(\text { Acala } 44 \mathrm{E} \times \mathrm{Ac} B_{I n}\right) \mathrm{F}_{1} \\
\text { Acala } 44 \mathrm{E} \times\left(\text { Acala } 44 \mathrm{E} \times \mathrm{Ac} B_{I n}\right) \\
\text { Ac } B_{I n} \times\left(\text { Acala } 44 \mathrm{E} \times \mathrm{Ac} B_{I n}\right) \\
\left(\text { Acala } 44 \mathrm{E} \times \mathrm{Ac} B_{I n}\right) \mathrm{F}_{2}\end{array}$ & $\begin{array}{l}(0: 1) \\
(1: 0) \\
(1: 0) \\
(1: 1) \\
(1: 0) \\
(3: 1)\end{array}$ & $\begin{array}{r}0 \\
46 \\
48 \\
48 \\
113 \\
234\end{array}$ & $\begin{array}{r}50 \\
0 \\
0 \\
55 \\
0 \\
71\end{array}$ & $\begin{array}{l}0.35 \\
0.39\end{array}$ & $\begin{array}{l}0.50-0.70 \\
0.50-0.70\end{array}$ \\
\hline $\mathrm{Ac}_{7}$ alternate $^{\mathrm{z}}$ & $\begin{array}{l}\text { Acala } 44 \mathrm{E} \\
\text { Ac } b_{7} \\
\left(\text { Acala } 44 \mathrm{E} \times \mathrm{Ac}_{7}\right) \mathrm{F}_{1} \\
\text { Acala } 44 \mathrm{E} \times\left(\mathrm{Acala} 44 \mathrm{E} \times \mathrm{Ac} b_{7}\right) \\
\text { Ac } b_{7} \times\left(\text { Acala } 44 \mathrm{E} \times \mathrm{Ac} b_{7}\right) \\
\left(\text { Acala } 44 \mathrm{E} \times \mathrm{Ac} b_{7}\right) \mathrm{F}_{2}\end{array}$ & $\begin{array}{l}(0: 1) \\
(1: 0) \\
(0: 1) \\
(0: 1) \\
(1: 1) \\
(1: 3)\end{array}$ & $\begin{array}{r}0 \\
46 \\
2 \\
10 \\
50 \\
73\end{array}$ & $\begin{array}{r}192^{\mathrm{y}} \\
0 \\
19 \\
108 \\
43 \\
169\end{array}$ & $\begin{array}{l}0.39 \\
3.17\end{array}$ & $\begin{array}{l}0.50-0.70 \\
0.05-0.10\end{array}$ \\
\hline
\end{tabular}


TABLE 3. Mean disease index, closest grade, and degree of dominance in field data for near-isogenic lines

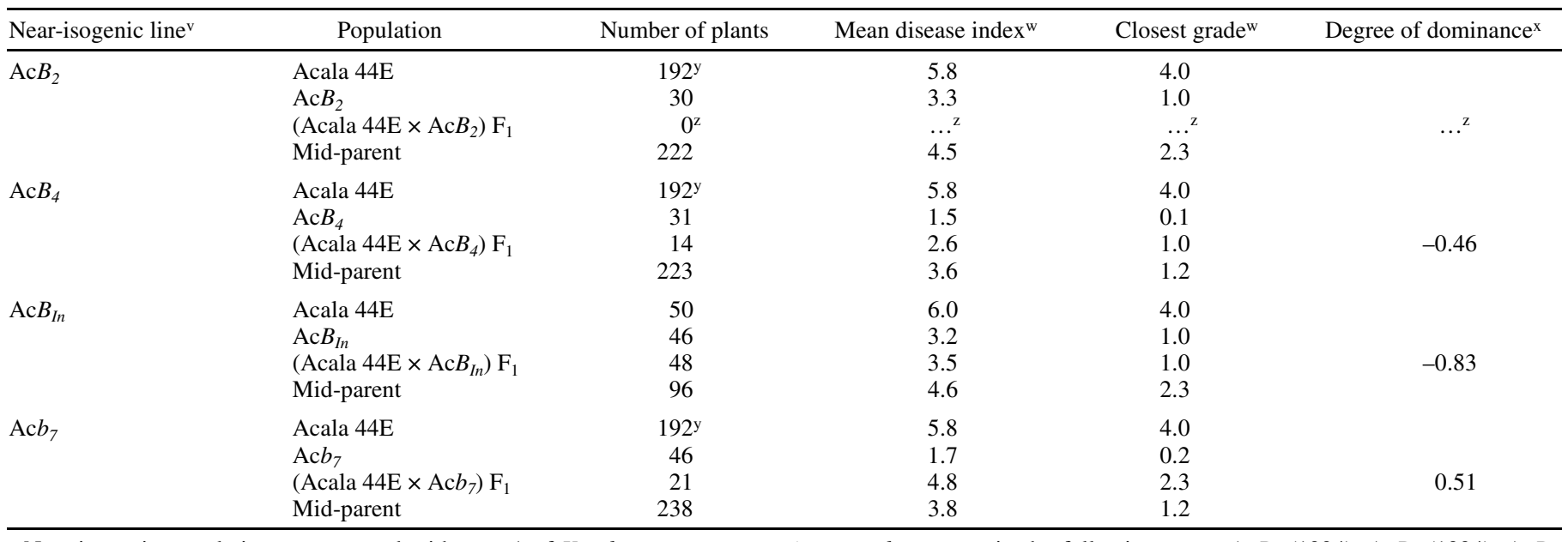

${ }^{\mathrm{v}}$ Near-isogenic populations were tested with race 1 of Xanthomonas campestris pv. malvacearum in the following years: $\mathrm{Ac} B_{2}(1994), \mathrm{Ac}_{4}(1994), \mathrm{Ac}_{I n}$ (1991), and Acb 7 (1994).

${ }^{\mathrm{w}}$ Disease indexes (and corresponding grades) were as follows: 0 (0.0), $1(0.1), 2(0.2), 3(1.0), 4(1.2), 5(2.3)$, and 6 (4.0). Blight grades ranged from 0.0 (immune) through 4.0 (susceptible).

${ }^{x}$ Degree of dominance calculations were based on disease index values. Negative estimates were toward lower (more resistant) grades; positive estimates were toward higher (more susceptible) grades. The resistant parent is scored as -1.00 , whereas the susceptible parent is scored as 1.00 .

y The total number of Acala 44E plants included in all test plots in 1994.

${ }^{\mathrm{z}}$ No $\mathrm{F}_{1}$ plants were available for this line in 1994.

TABLE 4. Comparisons of bacterial blight reactions in the field for host differential series and near-isogenic lines when tested with race 1 of Xanthomonas campestris pv. malvacearum

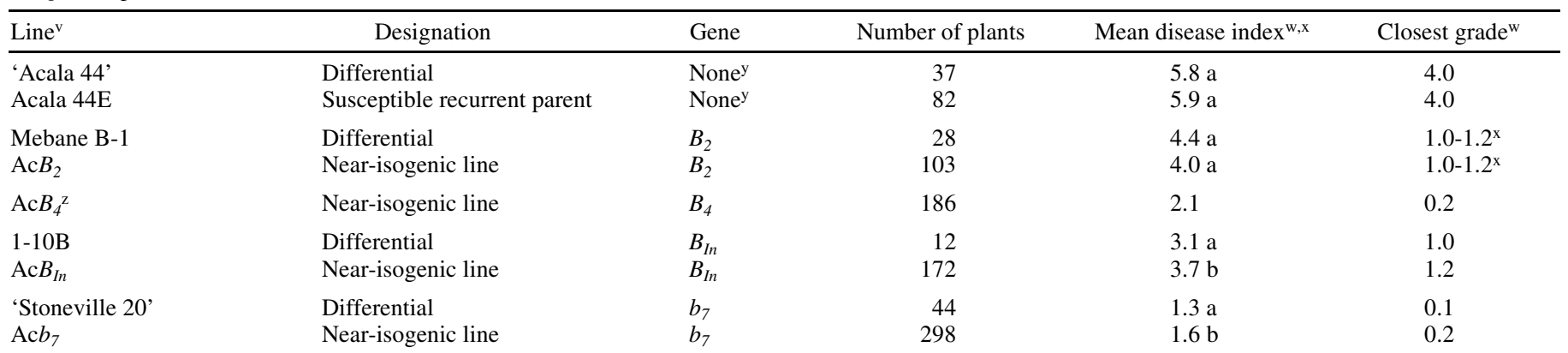

${ }^{\mathrm{v}}$ Near-isogenic and differential populations were tested in the following years: 'Acala 44' and Acala 44E (1993 and 1996), Mebane B-1 and AcB $B_{2}$ (1994, 1995, and 1996), $\mathrm{AcB}_{4}$ (1994, 1995, and 1996), 1-10B and $\mathrm{Ac} B_{I n}$ (1996), and 'Stoneville 20' and $\mathrm{Ac} b_{7}(1994,1995$, and 1996).

${ }^{w}$ Disease indexes (and corresponding grades) were as follows: $0(0.0), 1(0.1), 2(0.2), 3(1.0), 4(1.2), 5(2.3)$, and 6 (4.0). Blight grades ranged from 0.0 (immune) through 4.0 (susceptible).

${ }^{x}$ Within each pair of lines, mean values followed by the same letter were not significantly different according to an unpaired sample $t$ test at the 0.05 probability level.

y These entries appear to have some weak, segregating resistance.

${ }^{\mathrm{z}}$ There is no matching differential series host for $\mathrm{AcB}_{4}$.

the chi-square test indicating a single gene. The segregation pattern for this gene indicated that it was at least partially recessive, confirming its original report (11).

The degree and direction of dominance for genes $B_{4}$ and $B_{I n}$ were -0.46 and -0.83 toward the lower (more resistant) grades, respectively; for gene $b_{7}$, they were 0.51 toward the higher (more susceptible) grades (Table 3). Degree and direction of dominance were not calculated for $B_{2}$ because of the lack of $F_{1}$ data in the test year reported.

Comparisons were made between the reported disease grades for Brinkerhoff's differential series $(6,12,13)$ and our NILs Ac $B_{2}$, $A c B_{I n}$, and $A c b_{7}$ (Table 4). There is no matching line for $A c B_{4}$ in the differential series. In each case, the differential based on "mean disease index" exhibited equal or slightly greater disease resistance than our NIL (Table 4). The differentials containing $B_{I n}$ and $b_{7}$ were significantly more resistant than their corresponding NILs; $A c B_{2}$ equaled its differential, as did Acala 44E

The specificities of the bacterial blight-resistance genes toward six $a v r$ genes of $X$. campestris pv. malvacearum were tested
(Table 5). Fourteen to 20 plants of each NIL, grown in a growth chamber, were inoculated with the isogenic strains of $X$. campestris pv. malvacearum developed by De Feyter and Gabriel (8) and De Feyter et al. (9) which carry individual avr genes. The mean quantitative disease grades attained for all combinations of NILs and $a v r$ genes are shown in Table 5. The qualitative patterns of resistance and susceptibility deduced from the statistical relationships among those means are also shown in Table 5. Ac $B_{4}$ gave a resistant reaction only to the individual gene $a v r B_{4}$, as did $\mathrm{Ac} B_{I n}$ to $a v r B_{I n}$ and $\mathrm{Ac} b_{7}$ to $a v r b_{7}$. However, $\mathrm{Ac} B_{2}$ exhibited resistant reactions to genes $a v r B_{4}$ and $a v r B_{101}$; intermediate reactions to $a v r b_{6}, a v r b_{7}$, and $a v r B_{102}$; and a susceptible response to $a v r B_{I n}$.

\section{DISCUSSION}

Each of the four NILs was derived using at least six backcrosses to 'Acala 44' or Acala 44E. Therefore, on the average, each NIL was 99.2\% 'Acala 44' and/or Acala 44E (1). With a high 


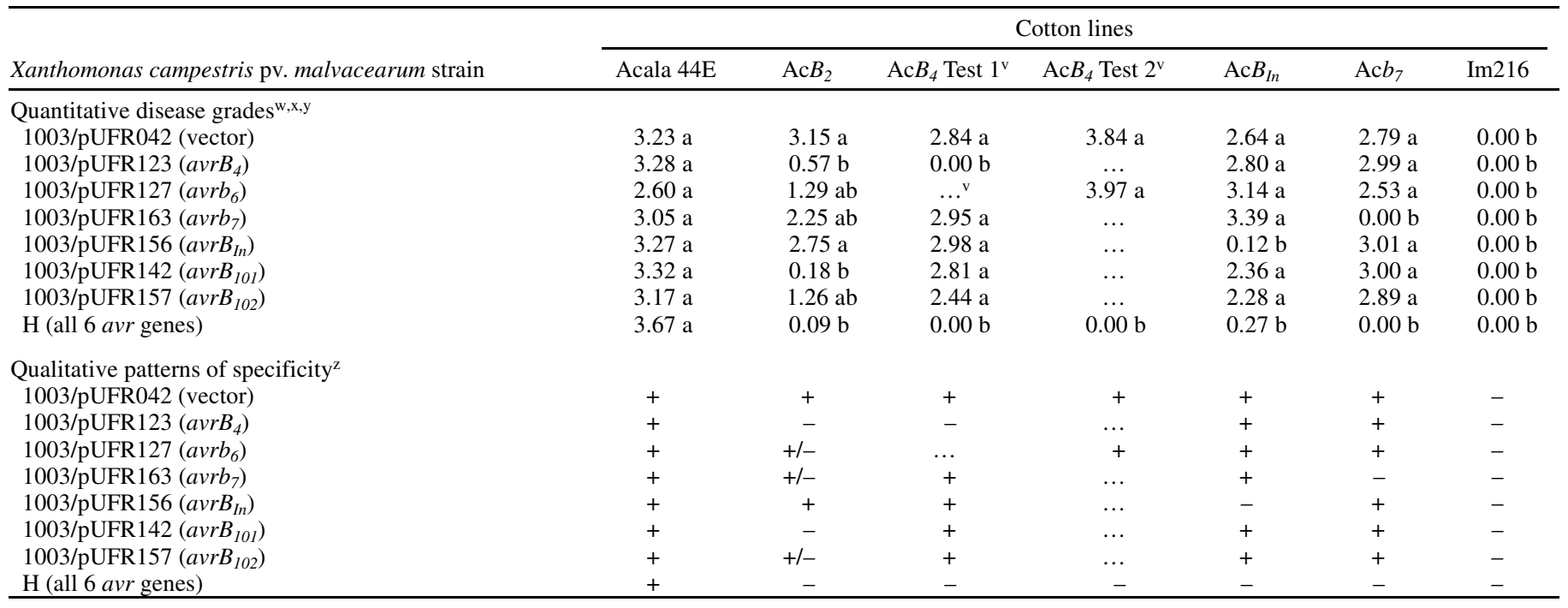

${ }^{\mathrm{v}}$ During test 1, the culture of strain 1003/pUFR127 $\left(\mathrm{avrb}_{6}\right)$ proved to be contaminated, which required the retesting of Ac $B_{4}$ in test 2.

${ }^{\mathrm{w}}$ Disease grade scale was as follows: $0=$ no water-soaking; $1=$ pinpoint-sized dots; $2=$ small, round speckles $(\approx 0.3 \mathrm{~mm}) ; 3=$ merged angular patches; $4=$ confluent areas. Intermediate grades between each of the established grades, e.g., 1.3, 2.7, and 3.3, were sometimes recorded.

${ }^{\mathrm{x}}$ Except for Acala 44E and $\operatorname{Im} 216$ (an immune line), each value is the mean for 14 to 20 plants of an individual near-isogenic line (NIL) grown and tested together. The Acala 44E and Im216 values are the overall means obtained from two plants of each that were grown and tested with each NIL.

${ }^{y}$ Within each column, mean values followed by the same letter were not significantly different according to a paired sample $t$ test at the 0.05 probability level.

${ }^{\mathrm{z}}$ The quantitative data determined the qualitative patterns.

degree of probability, differences between NILs can be attributed to their differences in genes for blight resistance. The NILs also underwent single plant-progeny row selection, which increased within-line uniformity for the trait selected (1). Each NIL appears to be homozygous for one of the blight-resistance genes $B_{2}, B_{4}$, $B_{I n}$, or $b_{7}$. Because resistance was retained through backcrosses in which the female parent was the susceptible recurrent parent, all are genes located in the cell nucleus, not in the cytoplasm. In the 'Acala 44'/Acala 44E background, $B_{2}, B_{4}$, and $B_{I n}$ were partially dominant; $b_{7}$ was partially recessive.

The slightly higher level of resistance found in the differential lines with genes $B_{I n}$ and $b_{7}$ than in these backcross lines is consistent with the hypothesis that those differentials contain polygenes that enhance resistance to race 1. In the backcross method, if the susceptible parent is used as the recurrent parent (as was done here), polygenes (with their small effects) tend to be lost with each cross (7). The backcross program followed herein appears to have had that result for those two NILs. Slight differences in closest field grades were noted for $\mathrm{Ac} B_{4}$ and $\mathrm{Ac} B_{I n}$ in Table 4 (1996) versus Table 3 (other years). These could have resulted from differences in environment and/or graders between those years.

The four bacterial blight-resistance genes differed in strength of resistance that they conferred toward $X$. campestris pv. malvacearum race 1 (as exemplified by strain $H$ ). Their strengths appeared to be somewhat dependent on environment, differing slightly from year to year in the field (Table 3 versus Table 4). In the growth chambers, all NILs were strongly resistant to race 1 (strain H). Approximately the same order of relative strength was observed in the field (Table 4 ) as in growth chambers (Table 5): $B_{4} \sim b_{7}>B_{\text {In }} \sim B_{2}$.

The testing of each NIL with individual isogenic races (Table 5) showed the $a v r$ gene specificity of each resistance gene. This race collection includes all six of the avr genes isolated by De Feyter and Gabriel (8) and De Feyter et al. (9). For the resistance genes common between our study and theirs, our pattern of host/race specificities is essentially the same as the one they observed (8), using the 'Acala 44' lines at an earlier stage in the backcross program. $B_{4}, B_{I n}$, and $b_{7}$ were each specific for one of the $a v r$ genes, thus they exhibited gene-for-gene relationships. The resistance in
$B_{2}$ was less specific (Table 5 ). Genetically, $B_{2}$ segregated as a single gene; but in reality, it could be two or more closely linked genes. Another intriguing possibility is that it could be a single gene exhibiting the horizontal characteristics of low specificity and low levels of resistance.

These single-gene NILs should prove useful to breeders interested in mapping or cloning the $B$ genes and to other researchers interested in studying the effects of genes which confer resistance to bacterial blight (without the complication of differing genetic backgrounds). The lines $\mathrm{Ac} B_{4}, A c B_{I n}$, and $A c b_{7}$ are currently being used in our program to construct a gene pyramid with all possible combinations of one, two, or three genes. That pyramid will be used to study the changes when multiple versus single resistance genes are present. Limited quantities of seed for each of the NILs can be obtained upon written request to Margaret Essenberg.

\section{ACKNOWLEDGMENTS}

The technical assistance of the following individuals is gratefully recognized: B. E. Greenhagen, J. Pitman-Winters, J. R. Steidl, R. L. Matheson and his staff at the Agronomy Research Station near Perkins, OK, and W. J. Malloy and his staff at the Tecomán Experiment Station near Colima, Mexico. We also thank R. De Feyter and D. W. Gabriel for providing us with many of the $X$. campestris pv. malvacearum strains used in this study. Approved for publication by the Director of the Oklahoma Agricultural Experiment Station and supported in part under project OKL01504.

\section{LITERATURE CITED}

1. Allard, R. W. 1960. Principles of Plant Breeding. John Wiley \& Sons, Inc., New York.

2. Bird, L. S. 1960. Developing cottons immune to bacterial blight. Pages 16-23 in: Proc. Cotton Improv. Conf. Nat. Cotton Coun., Memphis, TN.

3. Bird, L. S., Brinkerhoff, L. A., and Davis, R. G. 1981. Bacterial blight. Pages 25-28 in: Compendium of Cotton Diseases. 1st ed. G. M. Watkins, ed. The American Phytopathological Society, St. Paul, MN.

4. Blasingame, D., and Patel, M. V. 2000. Cotton Disease Loss Estimate Committee report. Pages 132-133 in: Proc. Beltwide Cotton Conf. P. Dugger and D. Richter, eds. Nat. Cotton Coun. of Am., Memphis, TN.

5. Brinkerhoff, L. A. 1963. Variability of Xanthomonas malvacearum: The 
cotton bacterial blight pathogen. Okla. Agric. Exp. Stn. Tech. Bull. T-98.

6. Brinkerhoff, L. A. 1970. Variation in Xanthomonas Malvacearum: The cotton bacterial blight pathogen. Annu. Rev. Phytopathol. 8:85-110.

7. Brinkerhoff, L. A., Verhalen, L. M., Johnson, W. M., Essenberg, M., and Richardson, P. E. 1984. Development of immunity to bacterial blight of cotton and its implications for other diseases. Plant Dis. 68:168-173.

8. De Feyter, R., and Gabriel, D. W. 1991. At least six avirulence genes are clustered on a 90-kilobase plasmid in Xanthomonas campestris pv. malvacearum. Mol. Plant-Microbe Interact. 4:423-432.

9. De Feyter, R., Yang, Y., and Gabriel, D. W. 1993. Gene-for-genes interactions between cotton $R$ genes and Xanthomonas campestris pv. malvacearum avr genes. Mol. Plant-Microbe Interact. 6:225-237.

10. Essenberg, M., Doherty, M. D., Hamilton, B. K., Henning, V. T., Cover, E. C., McFaul, S. J., and Johnson, W. M. 1982. Identification and effects on Xanthomonas campestris pv. malvacearum of two phytoalexins from leaves and cotyledons of resistant cotton. Phytopathology 72:1349-1356.

11. Green, J. M., and Brinkerhoff, L. A. 1956. Inheritance of three genes for bacterial blight resistance in upland cotton. Agron. J. 48:481-485.

12. Hunter, R. E., and Brinkerhoff, L. A. 1961. Blight differentials. Pages 78 in: Proc. Cotton Dis. Coun. Cotton Dis. Coun. and Nat. Cotton Coun. Memphis, TN.

13. Hunter, R. E., Brinkerhoff, L. A., and Bird, L. S. 1968. The development of a set of upland cotton lines for differentiating races of Xanthomonas malvacearum. Phytopathology 58:830-832.

14. Knight, R. L. 1948. The genetics of blackarm resistance. VI. Transference of resistance from Gossypium arboreum to G. barbadense. J. Genet. 48:359-369.

15. Knight, R. L. 1963. The genetics of blackarm resistance. XII. Transference of resistance from Gossypium herbaceum to G. barbadense. J. Genet. 58:328-346.

16. Knight, R. L., and Clouston, T. W. 1939. The genetics of blackarm resistance. I. Factors $\mathrm{B}_{1}$ and $\mathrm{B}_{2}$. J. Genet. 38:133-159.

17. Pierce, M. L., Essenberg, M., and Mort, A. J. 1993. A comparison of the quantities of exopolysaccharide produced by Xanthomonas campestris pv. malvacearum in susceptible and resistant cotton cotyledons during early stages of infection. Phytopathology 83:344-349.

18. Pinckard, J. A., Ashworth, L. J., Jr., Snow, J. P., Russell, T. E., Roncadori, R. W., and Sciumbato, G. L. 1981. Boll rots. Pages 20-24 in: Compendium of Cotton Diseases. 1st ed. G. M. Watkins, ed. The American Phytopathological Society, St. Paul, MN.

19. Strickberger, M. W. 1976. Genetics. 2nd ed. Macmillan Publishing Co., Inc., New York.

20. Wright, R. J., Thaxton, P. M., El-Zik, K. M., and Paterson, A. H. 1998. D-Subgenome bias of $\mathrm{Xcm}$ resistance genes in tetraploid Gossypium (cotton) suggests that polyploid formation has created novel avenues for evolution. Genetics 149:1987-1996. 